\title{
Impact of Business Ownership Change on Institutional Historical Knowledge Due to Employee Turnover: A Literature Review
}

\author{
M. A. K. De. S. Jayasekera \\ University of Sri Jayawardenapura, Sri Lanka \\ M. D. Pushpakumari \\ University of Sri Jayawardenapura, Sri Lanka
}

\begin{abstract}
Increasing number of business ownership changes and its impact on human capital is a global concern over the years. Change of business ownership of organisations can be in the form of Business Acquisitions. Mergers and Acquisitions are the most common form of Business Acquisitions. Business Acquisitions have made a significant impact on Human Resources in both acquirer and acquired organisations. Human Resource is also an important component of business integration process. Desired results of postacquisition hence can be hampered by the demotivated human resources. It is evident from literature that unless this sensitive area of human resources is not handled professionally, employees become reactive. The consequences can be damaging due to employee demotivation which can result in an increase in employee turnover after an ownership change. Retention of employees can be important to the acquirer companies since it can lose the Institutional Historical Knowledge with the parting of employees. The Institutional Historical Knowledge comprises of the knowhow an employee gained over the years of service in that particular institution and it includes 'tacit' knowledge which is competitively advantageous to the institution. This moves away with the employees
\end{abstract}

Corresponding Author:

Ms. M. D. Pushpakumari is a Senior Lecturer at the Department of Business Administration, University of Sri Jayewardenepura, Sri Lanka. E-mail: kkhmr222rathnayake@gmail.com 
leaving the organisation. The main objectivelaim of this study is to identify whether there is an impact of Business Ownership Change, on Institutional Historical Knowledge due to Employee Turnover - 'through literature. Hence, this paper reviews the theoretical findings in literature from business acquisitions, employee turnover and its impact on loosing Institutional Historical Knowledge-'the wisdom withdrawal'. The significance of the study is to echo the risk of losing Institutional Historical Knowledge due to employee turnover. Therefore, this study is totally a desk research based on literature review. The study reveals that there is a negative impact of business ownership changes on institutional historical knowledge due to employee turnover.

\section{Keywords}

Acquisitions, Employee Turnover, Institutional Historical Knowledge, Mergers

\section{Introduction}

Change of ownership of a business creates a change in the structure of ownership in an organisation. The change of ownership can happen in many ways; leverage buyouts, management buyouts, and Mergers and Acquisitions (M\&A). In any form of such change, former owners are more often replaced by a new set of investors. This buyout is undertaken for various reasons. M\&A has become a popular corporate restructuring method in developed and developing countries. In a business acquisition, one company/group of companies acquires the business of another company. It can be in the form of a merger. Merger is a combination of two companies in which only one corporation survives and the merged corporation goes out of existence (Gaughan 2011). Mergers can be two types. That is statutory and subsidiary. In a statutory merger where assets and liabilities of a company (merged) are acquired by the acquiring company. In a subsidiary merger, target company becomes a subsidiary or part of the parent company. In contrast, merger becomes a result of two equal size organisations respecting each other and forming a new entity, the change of investors can have positive and negative consequences on human resources. Impact of M\&A can be disastrous to the continuity of employment. After M\&A, the organisations - the merged and the acquired more often than not strategically introduce downsizing. In any way downsizing leads to 
employees leaving the organisation. The significant consequence of employees leaving voluntary or involuntary is the loss of organisational historical knowledge.

Employee turnover is the rate of which the employees leave the organisation over a period. The retention is the ability of employers to keep the employees in employment over a period. Employee retention is the ability of employees to retain its employees over a longer period of time. Employee retention is reflected by the organisations ability to reduce the employee turnover. Retention also explains the sustaining of employees for a continuous period. Turnover of employees varies markedly among industries. It is established that employee turnover affects the profits of a company. It is advantageous to employees in certain instances, who sacrificed their potential to be life time employed, in more comfortable work environment with the same employer, is forced to take a risk to change employment. Certain employees prefer long term employment. It could be due to the benefits of the permanent nature of employment such as entitlement for housing loan facilities make them stick to one organisation till their retirement and prevent them from leaving and live up to their potentials with another organisation. An employee's tenure with a firm tends to follow a familiar life cycle, from employment interviews to first job, promotion, transfer, and perhaps retirement. Companies in general have taken significant steps to overcome this situation of high employee turnover. Various strategies have been introduced. With the introduction of Human Resource Management (HRM) divisions, proper human resource planning was undertaken. Staff retention has become a challenge to every organisation, which operates in dynamic labour markets. It is therefore an important organisational problem. More attention has been paid to areas where the impact of business acquisition is affecting the organisational performance.

Organisations accumulate knowledge over the years and it is deposited in organisation human capital. It is this unique knowledge that gives the firm a competitive advantage. Knowledge that can be unique to the organisation is extended in the organisation human capital. Knowledge is codified in documentations such as manuals, circulars, etc. It is the explicit type of knowledge that is codified. Implicit knowledge is embedded in the 
social fabric of the organisation and is the organisation's 'tacit' knowledge. Tacit knowledge is developed and accumulated through the experience of individuals; hence it cannot be translated without the consent of the possessor of such knowledge. Institutional knowledge moves away with employees leaving the organisations or relocating themselves in other areas of business. Change of CEO's too contributes to the loss of institutional knowledge due to the change of agendas. Consequences of M\&A can be reshuffling of job roles which may cause the loss of institutional knowledge to the organisation. In this era of millennial and with the dawn of 2018 an organisation can consist of generations of individuals, the Baby Boomers, generation X, generation Y, and Millennial. Last of the baby boomers are on the verge of retirement. Skills and knowledge of baby boomers will be difficult for organisations to replace (Ashworth, 2006). The utility industry is one that affected most due to retirement of baby boomers in the next five to 10 years (Juliano, 2004). Consistency of the last lot of generation $\mathrm{X}$ and the entire generation of the generation $\mathrm{Y}$ with continuity of employment will be a major concern for organisations. It is noted in this era of 'skill mobility', from one organisation to another and one industry to another, it is difficult for organisations to capture the knowledge gained by individuals and transfer it to others. Organisations are without a program to capture and transfer the knowledge gained by leaving employees - the institutional historical knowledge. Under these circumstances this paper addresses the impact of business ownership change on institutional historical knowledge due to employee turnover. The methodology was a desk research based on literature review. This paper precedes as follows, literature review, discussion, and conclusion.

\section{Literature Review}

This section reviews the literature by carrying out a desk research in following areas; M\&A, Employee Turnover, Institutional Historical Knowledge and Organisational Memory, M\&A and its impact on loss of Knowledge due to Employee Turnover.

\section{Mergers and Acquisitions}

M\&A are form of ownership change, which makes fundamental changes in structure of ownership. This section reviews the literature on types of M\&A, recent resurgence, and the impact of M\&A on employees. 
M\&A can be categorized into the following ways, horizontal, vertical or conglomerate. In horizontal mergers, the two organisations which compete in the same field of business, form a combined organisation with a purpose of market expansion. A vertical merger is a combination of organisations that were in a buyer and seller relationship - for an example, a manufacturing company buying a distribution company. When the merger is not a combination of two companies which are in a competitive business nor have a buyer and seller relationship, it is known as a conglomerate. The authority is vested with the buyer (Schuler, Randall, \& Jackson, 2001). Mergers can be categorized as the combination of two social groups in to one and giving a new shape to these pre-merger groups. (Knippenberg, Knippenberg, Monden, \& Lima, 2002). These business acquisitions can be in the form of M\&A. In acquisitions, acquirer becomes dominant over acquirer firm whereas in mergers both companies are at equal platform (Karim, Nasir, Ameen, \& Ayaz, 2011). Between 1965 and 1985, 62,646 M\&A were recorded (Ellwood, 1987). Between 1980 and 1990, there have been approximately 23,000 M\&A. Only in 2004, 30,000 M\&A had taken place (Cartwright \& Cooper, 1990, Cartwright \& Schoenberg, 2006). M\&A could be strategically oriented, that is - cost reduction (Jensen, 1993; Wright, Hoskisson, \& Busenitz, 2001). Improving the organisational performance is the main objective of a business acquisition. It can happen through restructuring and reorientation of organisational resources and processes (Thompson \& Wright 1995). Employees can be affected by this restructuring. The restructuring of ownership can affect the existing employee relations (Pendleton, Wilson, \& Wright, 1998). Employee relations vary with every organisational change. Certain features of employee relations can be affected by organisational changes. It is noted that many factors have been responsible for the failure of M\&A activities such as, changes in business environment, process integration, regulatory impacts, customer attitudes, and employees and managerial issues (Mittal \& Jain, 2012). Effective HRM is a key factor of financial performance in M\&A (Qureshi, Hafeez, Sharif, Butt, \& Bilal, 2011). The HRM is a critical factor in the success of M\&A (Vazirani, 2012). It is critically important to retain and motivate the talented employees for a successful integration in M\&A (Kay \& Shelton, 2000). These business acquisitions can be in the form of M\&A, the companies armed with these strategic changes, to achieve 
a competitive advantage. However, these changes have rarely achieved the objectives that it was intended to achieve (Beer, Eisenstat, \& Spector, 1990; Taylor-Bianco \& Schernerhorn, 2006). A different opinion has expressed by (Sonenshein, 2010). Successful implementation of strategic change can reinvigorate a business also failure can lead to catastrophic consequences including decline of firms. Many researches confirmed that there had not been any successful bank mergers with neglecting human factors (Kahr, 2011; Schweiger \& Ivancevich, 1985; Schweiger \& Weber, 1989; Cartwright \& Cooper, 1993; Buono \& Bowditch, 2003).

Organisations adjust their process both internal and external to face these challenges, internal such as HRM systems, downsizing, job enhancements and enlargements, and upgrading information technology systems. External processes needs to be reconfigured by readjusting these processes to face changes in business environment (Freese \& Schalk, 2002; Bellou, 2006; Tomprou, Nikolaou, \& Vakola, 2012; Burke, 2013). Theses changes can affect human resources of any organisation. Human resources are sensitive resources in any organisation. Any adverse result of change could have negative socio economic effect. Some merged companies down size by laying-off employees (Brockner, 1988). These changes can have drastic consequences for employees who lose their jobs, and could result in negative impact on the remaining employees (Latack \& Dozier 1986; Sverke \& Hellgren, 2001). If effect on employees is positive it will be a gain in takeovers. It is noteworthy to understand what causes employees perceptions of anticipatory negligence of obligations, on the part of the employer. Organisational change can cause employees negative perceptions with regard to the non-fulfilment of obligatory requirements (Turnley \& Feldman, 2000; Beaumount \& Harris, 2002; Bartlett \& Ghoshal, 2000; Freese, Schalk, \& Croon, 2011). The changes of ownership will change employee roles. Employees will face conflicting situations which can result in employees in a dilemma. The roles that employees are supposed to play and tasks they are supposed to achieve can be a deciding factor, which influences the decision to leave the organisation (Igbaria \& Siegel, 1992). The employees become dissatisfied with new job roles and tasks that are to be performed after a business acquisition. This may result in less commitment to the job. Job satisfaction and organisational commitment are inter-related and causes the employee turnover (Price, 2001; Arkoubi, 
Bishop, \& Scott, 2007). When an employee is not satisfied with the job, employees like to withdraw from their work. Job satisfaction can be a deciding factor for job continuation or withdrawal. Employees who are satisfied with the job remains with the organisation and those who are not satisfied leave the organisation (Noe, Hollenbeck, Gerhart, \& Wright, 2010). The acquisitions can be motivated by the potential to achieve efficiencies. Present day organisations face many challenges such as, increase in costs, globalisation of markets, change of governmental policies, strategic partnerships entered by governments, increased competition, information and technology improvements, and government regulations (Freese \& Schalk, 2002). In order to be competitive among these multiple changes organisations consider changing their strategies and structures.

\section{Employee Turnover}

Employee turnover has drawn attention of both academics and management. A considerable amount of research has been done on antecedents and consequences of employee turnover. The following review identifies the causes of employee turnover and its impact on business.

Employee turnover can be either voluntary or involuntary and the cost of it is unavoidable (Price, 2001). A contradictory opinion was expressed by Taylor (2005) that it is an avoidable cost and human resource managers in recent times view high turnover of certain type of employees, leaving the organisation as an advantage to the company. This is essentially not high flyers. Human resource retention policies are prepared to keep the high flyers from leaving. The employer's career development responsibilities change as the employee moves through the scale (Dessler, 2013). High employee turnover creates flexibility in the employment market. Employers sometimes believe that the high employee turnover is inevitable (Taylor, 2005). Therefore, it is therefore employee turnover as an additional cost to the organisation. This additional cost includes cost of training and development given to the employee who left the organisation, cost of hiring a new employee, and cost of management time for administering the recruitment process cost of training such hired employees, and opportunity cost of hiring (Taylor, 2005). Companies instead of incurring this cost are now determined to implement strategies to keep their employees happy within the organisation. Special efforts are being made to prevent the high 
flyers from leaving high turnover is viewed as an evidence of a poorly managed company (Taylor, 2005). Finding the best talent has always been critical for business organisations. Human resource divisions should have an excellent recruitment process to recruit such talents (Weiss, 2013). Keeping the best talent within the organisation is crucial to all employers. They adopt various methods to keep them within the organisation. Decision to leave organisation can be made at the spur of the moment, but as per Taylor, (2005) it accounts only for a minority of departures. It is a well thought out decision employees take to leave the organisation. As for Taylor (2005), the majority of voluntary turnover is based on decisions planned and worked out on a long drawn out process. The immediate ancestor of HRM is the Personnel Management. (Tayeb, 2005). Personal departments or the present day Human resource divisions are required to meet certain regulatory requirements for employee benefits. As per Tayeb (2005, p5), "HRM deals with personnel functions, but these are planned and implemented with regard to the overall strategies of the company and the ways in which human resources can contribute to those strategies." Institute of Personal Management (IPM) of Sri Lanka defines HRM as "a strategic and integrated approach in acquisition, development, and engagement of talents using relevant tools with proper policies, practices, and processes in creating a conducive climate towards achieving excellence and social wellbeing" (www.ipm.lk.org). As per Ulrich, Brockbank, Johnson, Sandhol and Younger (2008, p1), "HRM wants to add value contribute in meaningful ways to employees, the line managers inside the company and to customers, communities, partners and investors outside the company". Operational and policy issues were the primary work performed by personnel department (Ulrich et al, 2008).

Human resource practices should be aligned with external expectations. New employees should be hired based on how well they demonstrate the skills and abilities the customer expects. Human resource department like any business needs a clear strategy (Ulrich et al., 2008). As per Weiss (2013, p5), "human resource to be a driver of strategic business leadership, it must take on outside-in perspective rather than inside-out perspective. An outside- in perspective means that human resource focuses on the business and the value that the business creates for its external customers and then used those insights to determine what human resource should do to deliver 
business value. With an inside-out perspective human resource looks at itself and decides what the business needs based upon its view of the right things to do". There can be beneficiaries among the employees. Competent Managers can be the complements of M\&A. (Brockner, 1988; Jovanovic \& Rousseau, 2002). Employees leave organisations due to poor job satisfaction and lack of organisational commitment. Fondness to work and the job is the job satisfaction and employees' commitment to the organisational success is organisational commitment (Price, 2001). As the employees who are not competent or not achieving the expected level by performance is more vulnerable to these changes. There can be downsizing as a strategic option. It can be described as a management objective to improve organisational performance and to gain a competitive advantage (Freeman \& Cameron, 1993). Yet, downsizing can affect negatively on its performance as downsizing is more often a short-sited activity (Cascio, 1993). It affects the organisation performance negatively (Shaw, Gupta, \& Delery, 2005). Downsizing is described as a planned elimination of employees excluding employee services which were discontinued for a valid reason, the voluntary resignation of employees, and employees leaving after reaching the age of retirement (Cascio, 1993).

\section{Institutional Historical Knowledge}

Institutional historical knowledge has drawn academic attention. This section reviews the importance of employees' accumulated knowledge and the consequences of knowledge loss

It is a societal threat that the next few decades will see an increasingly ageing workforce (Foster, 2005), also among the young employees (DeLong \& Davenport, 2003). This could result in knowledge losses. It is the knowledge gained by ageing employees, and it could be invaluable, irreplaceable and specialised knowledge that the organisations lose (DeLong, 2004; Salopek, 2005; Doyle, 2004). Initially it was argued that this knowledge has the most valuable resource (Grant, 1996a; Zack, 1999). It is the human capital that the employees accumulate which moves with employees when the employee leaves the organisation. Contradicting arguments were put forward by Starke, Dyck and Mauws (2003) that employee turnover does not affect the performance of the organisation. Pickett (2004) on the other hand argues that the knowledge gained by 
employees will leave with them when employees leave. The knowledge has passes from one generation to another, using different methods. Such as, face to face and hands on methods (Hansen, Nohria, \& Tierney, 1999). In organisations, knowledge is combined and nested in the minds of people (Wah, 1999; Bonner, 2000; Lee, 2000). With the dawn of information age, there had been an unprecedented demand for knowledge workers. The importance of giving prominence to the knowledge and recruiting people who could gain knowledge and apply efficiently are in demand and who has the competence to manage and use these human resources has an advantage as a manager. The leaders who could use imagination and intuitiveness and are inspirational who can manage and derive maximum benefits have the advantage in an organisation (Goffee \& Jones, 2000).

Knowledge severs as an important factor and it is competitively advantageous to the organisation (Hitt, Bierman, Shimizu, \& Kochhar, 2001). Since human capital is competitively advantageous to the organisation, it needs to understand the same, and win the war for talent (Gardner, 2005). Organisations have to use different strategies to attract the best talent. HRM practices are focused to recruit the best for high investment companies which give them a competitive advantage (Delery \& Shaw, 2001). It is the knowledge that is included in the goods and services that people buy. It is therefore an important factor in a man's economic life. Knowledge can be a main business influence (Quintas, 2002). Knowledge can be regarded as a valuable asset in making the organisation competitively advantageous (Bender \& Fish, 2000; Wong \& Radcliffe, 2000). It is startling to note that 99 per cent of people's work in organisation is based on knowledge (Wah, 1999). Knowledge increases the bottom line (Pascarella, (1997).

\section{Organisational Memory}

This section of the literature review identifies the different academic explanations and descriptions of organisational memory.

Organisational memory can be described as the organisation's historical knowledge that can be used to shape the subsequent decisions (Walsh \& Ungson, 1991). Organisational memory is knowledge, which is retained with individual employees, group of employees, and organisations (Argote, 
McEvily, \& Reagans, 2003). Retained knowledge also can be explained as the information stored, the challenges, and problems overcome and the responses made (Anderson \& Sun, 2010). The retained knowledge which is critical is valuable to organisations. It does contribute to the organisational success (Nonaka, 1994). Employees leaving the organisation result in a loss of organisational memory (Dougherty \& Bowman, 1995). Contradicting views were also expressed that retained knowledge can also reduce flexibility to adjust to changing situations (Shin, Holden, \& Schmidt, 2001), increases inefficiencies within organisation (Levitt \& March, 1988), prevent challenging the status quos of organisation (Argyris \& Schon, 1978). Largely undocumented experience, insights, knowledge, and skills acquired over the years passed on to the newcomers through personal contacts, meetings, training courses, and mentor-protege relationships. Organisational memory (unless pooled and recorded in a readily accessible form such as a database) is destroyed through excessive downsizing, frequent layoffs, unmanaged employee attrition, and/or disasters. Organisational memory sometimes called institutional or corporate memory, which is the accumulated body of knowledge created in the course of an individual organisations' existence

Knowledge can be advantageous to an organisation (Grant, 1996b). Losing knowledge can give adverse results, mainly the loss of organisational memory (Shah, 2000). Reduction in organisational output is a result of knowledge loss (Droege \& Hoobler, 2003). The tacit knowledge of an organisation is difficult for another organisation to copy (Barney, 1991). Tacit knowledge is intuitive and cannot be articulated (Hedlund, 1994) which remains with employees. Human resources are valuable and scarce in supply thus they can hold knowledge that is tacit (Coff, 1997). The knowledge that is not spoken and hidden within the minds of employees is the tacit knowledge (McInerney, 2002). It involves employees' experiences gained (Alavi \& Leidner, 2001). Explicit knowledge is coded and remains with organisations (Nonaka, 1994). The knowledge that is unique to the organisation when integrated can be advantageous to the organisation (Grant, 1996; Leonard-Barton, 1992). It is observed that when the employees leave the organisation lose employees' tacit knowledge which can negatively affect the organisations' capability (Nelson \& Winter, 1982). 
It can be in the form of knowledge acquired through relations with business partners (Stewart, 1998)

\section{Mergers and Acquisition and Its Impact on Loss of Knowledge, Due to Employee Turnover}

It is the feeling of alienation that employees of merged or acquired companies experience during the process of integration, they feel the loss of colleagues at work and the reduction of benefits offered by previous employer (Buono \&Bowditcth, 1989; Seo \& Hill, 2005). When employees hear the news of a business ownership structure change, they become anxious. M\&A are such anxiety provoking and adding stressful experience to employees. (Bouno \& Nurick, 1992; Marks \& Marvis ,1992). This may affect employee commitment. It is said to be declining and their reactions becomes negative when the announcement of M\&A is made (Klendauer \& Deller, 2009; Marks \& Mirvis, 1992; Meyer \& Allen, 1997; Raukko, 2009; Seo \& Hill, 2005). A dissatisfied employee may become less committed. There is a negative relationship between organisational commitment and the intention to leave and the employee turnover (Meyer \& Allen, 1997). It can affect employment security, where the employees become vulnerable to global competition and threats to the security of employment and knowledge and experience that exits in their brain can disappear with them before it transferred to the new employees (Delong, 2004). Employees who leave the organisation take with them the knowledge and experience gained during employment - 'the institutional historical knowledge'. Unless there is a mechanism to transfer such knowledge employee carry with them knowledge so gained. Key employees leave before transferring the knowledge or expertise to new employees or colleagues can result delays, costly errors, and inefficiency may happen, thus impacting organisational performance (Marks, 2006; Marks \& Mirvis, 1992; Rafferty \& Restubog, 2010; Terry, Carey, \& Callan, 2001).

\section{Discussion}

The study aimed at reviewing existing literature with regard to the impact of employee turnover on the loss of institutional historical knowledge, the cause of volunteer employee turnover due to the change of ownership. Few waves of M\&A had taken place during the recent past resulting changes in ownership structures. As per Ellwood (1987) there had been 62,646 M\&A 
taken place between 1965-1980. Whereas during 1980's and 2004 approximately 23,000 and 30,000 M\&A have taken place respectively (Cartwright \& Cooper 1990; Cartwright \& Schoenberg 2006). Jensen, (1993) and Wright, Hoskisson and Busenitz, (2001) discuss M\&A as a strategic orientation for reduction of cost. In recent research findings Karim and Capron (2016) argues that M\&A provide grounds to redeploy, recombine, and divest asset with a purpose of strengthening the organisations pool of resources. Thompson and Wright (1995) are of the opinion that in order to improve the organisational performance, which is the main purpose of a M\&A by restructuring and re-orientation of resources and processes. An important resource is the organisations human resources. It is the human resource factor, which is critical to a successful M\&A (Vazirani, 2012). Therefore, as per Kay and Shelton (2000), it is critically important to retain and motivate the talented employees for a successful integration in M\&A. As per Kahr (2011), Schweiger and Ivancevich, (1985), Schweiger and Weber(1989), Cartwright and Cooper (1993), and Buono and Bowditch (2003) there had not been any successful bank mergers with neglecting human factors. A serious consequence of an acquisition is the change of job roles of certain employees causing them to leave the employer while others will remain with the organisation. Igbaria and Siegel (1992) argues about the roles employees are supposed to play and tasks they are supposed to achieve which can influence the decision of employees to leave the organisation. Downsizing employee carder is another strategy the organisations introduce after M\&A. This can affect performance negatively (Shaw et al., 2005). Casico (1993) opines that it is a short-sited activity and it negatively affects performance. Carder reduction will result in employees loosing employment with employer and unhappy employees leave on their own account. Chadwick (2017) argues that in a recessionary environment the value of human capital can be less than that of a developing market. These employees carry with them the knowledge they gained while being in employment with the organisation, which can be unique to the organisation. It includes tacit knowledge which is advantageous to the organisation. Hitt et al. (2001) confirms that knowledge severs as an important factor and it is competitively advantageous to the organisation. Knowledge is included in the goods and services organisation offer, therefore it can be considered as an important factor in a man's economic life. Accumulated knowledge of human resources is an asset to 
the organisation and it can be a main business influence as stated by Quintas (2002). Knowledge gives and edge to the organisation over others in completion. Bender and Fish (2000) and Wong and Radcliffe (2000) confirm that knowledge can be regarded as a valuable asset in making the organisation competitively advantageous. Organisations' foundation is the organisational accumulated knowledge. This is confirmed by Wah (1999) stating that it is startling to note that 99 per cent of people's work in organisation is based on knowledge. Knowledge gives the advantage and increase revenue. Arora, Belenzon and Rios (2014) is of the opinion that organisational design has an effect on integration of knowledge; more internal knowledge is attracted in centralized structures and more external is attracted in decentralizes structures. As per Pascarella (1997), Knowledge increases the bottom line. Organisations over the years have accumulated knowledge and it is deposited in an employee and is identified as organisational memory. Walsh and Ungson (1991) describe it as the organisation's historical knowledge that can be used to shape the subsequent decisions. Argote et al. (2003) identifies it as the knowledge which is retained with individual employees, group of employees, and organisations. The knowledge that is all encompassing, accumulated, and retained while in employment with the particular organisation is authentic to organisations. Anderson and Sun (2010) explain retained knowledge as the information stored, the challenges and problems overcome, and the responses made McInerney (2002) identifies knowledge that is not spoken and hidden within the minds of employees as tacit knowledge. Alavi and Leidner (2001) state that it involves employees' experiences gained. It is this retained knowledge that is the organisational historical knowledge that employees carry with them when they leave the organisation. Organisations have so far not found a sound system to capture and transfer this knowledge to another employee. Since there is no mechanism to identify the areas of these domains of knowledge, no proper attention has been paid yet to value the loss of institutional historical knowledge.

\section{Conclusion}

This article reviews literature relating to the impact of business ownership change on institutional historical knowledge due to employee turnover. Business acquisitions, which take place globally via M\&A have a direct impact on continuity of employment. After the acquisition, the acquired 
company re-orient its processes and resources to improve performance, which can affect human resources too. There can be carder adjustments, which disturb the continuity of the employment. This may be due to planned downsizing of employment capacity or voluntary resignations of employees. It is evident from the literature that M\&A affect the employee performance negatively due to downsizing and change of job roles. These affected employees leave the employer and may join a competitor. They carry valuable experience and knowledge with them. It can be concluded that the result of employee turnover is a loss of organisational historical knowledge. Employees leave the organisation with the knowledge acquired in employment. The most significant consequence is the loss of tacit knowledge which is intuitive and difficult to replace. Organisations are yet to find a mechanism to capture this historical knowledge. The reviewed literature identified many gaps in research. One such area is lack of methodology to identify the areas of institutional knowledge hence it is recommended that further research could be carried out to identify the domains of historical knowledge

\section{References}

Alavi, M.., \& Leidner, D. E. (2001). Review - knowledge management and knowledge management systems: Conceptual foundations and research issues. MIS Quarterly, 25(1), 107-136.

Argyris, C., \& Schon, D. A., (1978). Organisational learning: A theory of action perspective reading. Boston, MA: Addison-Wesley.

Anderson, M. H., \& Sun, P. Y. T. (2010). What have scholars retrieved from Walsh and Ungson (1991)? - A citation context study. Management Learning, 41(2), 131-145.

Argote, L., McEvily, B., \& Reagans, R. (2003). Managing knowledge in organisations: An integrative framework and review of emerging themes. Management Science, 49(4), 571-582.

Arkoubi, K. A., Bishop., J. W., \& Scott, D. (2007). An Investigation of the determinants of turnover intention among drivers. Oxford, MS: South West Decision Sciences Institute Federation of Business Disciplines, University of Mississippi. 
Arora, A., Belenzon, S., \& Rios, L. A. (2014). Make, buy, organize: the interplay between research, external knowledge, and firm structure. Strategic Management Journal, 35(3), 317-337.

Ashworth, M. J. (2006). Preserving knowledge legacies: Workforce aging, turnover and human resource issues in the US electric power industry. International Journal of Human Resource Management, 17(9), 16591688.

Barney, J. (1991). Firm resources and sustained competitive advantage. Journal of Management, 17, 99-120.

Bartlett, C. A., \& Ghoshal, S. (2000). Going global lessons from late movers. Harvard Business Review, 78(2), 132-142.

Beaumount, P. B., \& Harris, R. I. (2002). Examining white-collar downsizing as a cause of change in the psychological contract: Some UK evidence. Employee Relations, 24(4), 378-388.

Beer, M., Eisenstat, R. A., \& Spector, B. (1990). Why Change programs don't produce change. Harvard Business Review, 68(6), 158-66.

Bellou, V. (2006). Psychological contract assessment after a major organisational change: The case of mergers and acquisitions. Employee Relations, 29(1), 68-88.

Bender, S., \& Fish, A. (2000). The transfer of knowledge and the retention of expertise: The continuing need for global assignment. Journal of Knowledge Management, 4(2), 125- 137.

Bonner, D. (2000). Knowledge: From theory to practice to golden opportunity. American Society for Training \& Development, September-October, 12-13.

Brockner, J. (1988). Self-esteem at work. Lexington, MA: Lexington Books. Buono, A. F., \& Nurick, A. J. (1992). Intervening in the middle: Coping strategies in mergers and HR. Human Resource Planning, 15(2), 19-19.

Buono, A. F., \& Bowditch, J. L. (1989). The human side of mergers and acquisitions: Managing collisions between people, cultures, and organisations (2nd ed.). Washington, DC: BeardBooks.

Buono, A. F., \& Bowditch, J. L. (2003). Human side of mergers and acquisitions: Managing collisions between people, cultures and organisations. Washington DC: Beard Books.

Burke, W. W. (2013). Organisational change: Theory and practice. Sage California: Publications. 
Cartwright, S., \& Cooper, C. L. (1990). The impact of mergers and acquisitions on people at work: Existing research and issues. British Journal of Management, 1, 65-76.

Cartwright, S., \& Cooper, C. L. (1993). The psychological impact of mergers and acquisitions on the individual: A study of building society managers. Human Relations, 46, 327-347.

Cartwright, S., \& Schonberg, R. (2006). Thirty years of mergers and acquisitions research: Recent advances and future opportunities. British Journal of Management, 17(1), 51-55.

Cascio, W. F. (1993). Downsizing: What do we know? What have we learned? Academy of Management Executive, 7(1), 95-104.

Chadwick, C. (2017). Toward a more comprehensive model of firms' human capital rents. Academy of Management Review, 42, 499-519.

Coff, R. (1997). Human assets and management dilemmas: Coping with hazards on the road to resource-based theory. Academy of Management Review, 22, 374-402.

Delery, J. E., \& Shaw, J. D. (2001). The strategic management of people in work organisations: Review, synthesis, and extension. Research in Personnel and Human Resource Management, 20, 165-197.

Dessler G. (2013). Human resource management (3rd ed.). UK: Pearson Education Ltd.

DeLong, D. W., \& Davenport, T. (2003). Better practices for retaining organisational knowledge: Lessons from leading the edge. Employment Relations Today, 30(3), 51-63.

DeLong, D. W. (2004). Lost knowledge: Confronting the threat of an aging workforce. Oxford: Oxford University Press.

Dougherty, D., \& Bowman, E. H. (1995). The effects of organisational downsizing on product innovation. California Management Review, $37(4), 28-44$.

Doyle, S. (2004). Lost knowledge: Confronting the threat of an aging workforce. People Management, 10(25), 45.

Droege, S. B., \& Hoobler, J. M. (2003). Employee turnover and tacit knowledge diffusion: A network perspective. Journal of Managerial Issues 15(1), 50-61.

Ellwood, J. W. (1987). The impact of mergers and acquisitions on the governance of the modern corporation: Theories and evidence. In Logue 
D. E. (Eds.), Handbook of modern finance: 1987 update. Boston, MA: Warren, Gorham \& Lamont.

Foster, L. (2005). Confronting the global brain drain. Knowledge Management Review, 8(5), 28-31.

Freeman, S. J., \& Cameron, K. S. (1993). Organisational downsizing: A convergence and reorientation framework. Organisation Science, 4(1), $10-29$.

Freese, C., \& Schalk, R. (2002). The impact of organisational changes on the psychological contract and attitudes toward work in four health care organisations. In: Isaksson K., Hogstedt C., Eriksson C., Theorell T. (Eds). Health Effects of the New Labour Market, (pp.129-143). Boston, MA: Springer

Freese, C., Schalk, R., \& Croon, M. (2011). The impact of organisational changes on psychological contracts: A longitudinal Study. Personnel Review, 40(4), 404-422.

Gardner, T. M. (2005). Human resource alliances as a means of improving the recruiting, management, and retention of employees. International Journal of Human Resource Management, 16(6), 1057-1074.

Gaughan, P. A. (2011). Mergers, acquisitions, and corporate restructurings. UK: John Wiley \& Sons Inc.

Goffee, R. \& Jones, G. (2000). Why should anyone be led by you? Harvard Business Review, 78(5), 62-70.

Grant, R. M. (1996a). Toward a knowledge-based theory of the organisation. Strategic Management Journal, 17, 109-22.

Grant, R. (1996b). Prospering in dynamically-competitive environments: Organisational capability as knowledge integration. Organisation Science, 7, 375-387.

Hansen, M. T., Nohria, N., \& Tierney, T. (1999). What's your strategy for managing knowledge? Harvard Business Review, 77(2), 106-116.

Hedlund, G. (1994). A model of knowledge management and the N-form corporation. Strategic Management Journal 15(2), 73-90.

Hitt, M. A., Bierman, L., Shimizu, K.., \& Kochhar, R. (2001). Direct and moderating effects of human capital on strategy and performance in professional service firms: A resource-based perspective. Academy of Management Journal, 44(1), 13-28. 
Igbaria, M., \& Seigel, S. R. (1992). An examination of the antecedents of turnover propensity of engineers: An integrated model. Journal of Engineering and Technology Management, 9(2), 101-126.

Jensen, M.C. (1993). The modern industrial revolution, exit and the failure of internal control systems. Journal of Finance, 48, 831-80.

Jovanovic, B., \& Rousseau, P. (2002). Mergers as reallocation. The Review of Economics and Statistics, 90(4), 765-776, 07.

Juliano, J. J. (2004). Gen-X and Gen-Y: Teaching them the business. Public Utilities Fortnightly, 142(6), 82-85.

Kahr, A. (2011). Profitability comes down to staff cuts. American Banker, 176(127), 8.

Karim S., \& Capron, L. (2016). Reconfiguration: adding, redeploying, recombining and divesting resources and business units. Strategic Management Journal, 37(13), 1-20.

Karim, Nasir, Ameen, A., \& Ayaz, M. (2011). Mergers and acquisitions: An impact on financial performance. Interdisciplinary Journal of Contemporary Research in Business, 3(1), 804-813.

Kay, I. T. \& Shelton, M. (2000). The people problem in mergers. The McKinsey Quarterly, 4, 27-37.

Klendauer, R., \& Deller, J. (2009). Organisational justice and managerial commitment in corporate mergers. Journal of Managerial Psychology, 24(1), 29-45.

Knippenberg, D., Knippenberg, B., Monden., L. \& Lima, F., (2002). Organisational identification after a merger: A social identity perspective. British Journal of Social Psychology, 41, 233-252.

Latack, J. C., \& Dozier, J. B. (1986). After the axe falls: Job loss as a career transition. Academy of Management Review, 11(2), 375-392.

Lee, J. (2000). Knowledge management: the intellectual revolution. IIE Solutions, October, 34-7.

Leonard-Barton, D. (1992). Core capabilities and core rigidities: A paradox in managing new product development. Strategic Management Journal, 13, 111-125.

Levitt, B., \& March, J. G. (1988). Organisational learning. Annual Review of Sociology, 14, 319-340.

Marks, M. L., \& Mirvis, P. H. (1992). Rebuilding after the merger - Dealing with survivor sickness. Organisational Dynamics, 21(2), 18-32. 
Marks, M. L. (2006). Workplace recovery after mergers, acquisitions, and downsizings: Facilitating individual adaptation to major organisational transitions. Organisational Dynamics, 35(4), 384-399.

McInerney, C. (2002). Knowledge management and the dynamic nature of knowledge. Journal of the American Society for Information Science and Technology, 53(12), 1009-1018.

Meyer, J. P., \& Allen, N. J. (Eds.) (1997). Commitment in the workplace: Theory, research, and application. Thousand Oaks: Sage Publications.

Mittal, Anshu \& Jain, P. K. (2012). Mergers and acquisitions performance system: Integrated framework for strategy formulation and execution using flexible strategy game-card. Global Journal of Flexible Systems Management, 13(1): 41-56.

Nelson, R. R., \& Winter, S. (1982). An evolutionary theory of economic change. Cambridge, MA: Harvard University Press.

Noe, R. A., Hollenbeck, J. R., Gerhart, B., \& Wright, P. M. (2010). Human resource management - Gaining a competitive advantage. New York: McGraw Hill.

Nonaka, I. (1994). A dynamic theory of organisational knowledge creation. Organisation Science, 5, 14-37.

Pascarella, P. (1997). Harnessing knowledge. Management Review, 86(9), 37-40.

Pendelton, A., Wilson, N., \& Wright M. (1998). The perceptions and Effects of share ownership: Empirical evidence from employee buy-outs. British Journal of Industrial Relations, 1(36), 99-124.

Pickett, L. (2004). Focus on technology misses the mark. Industrial and Commerce Training, 36(6/7), 247-249.

Price, J. L. (2001). Reflections on the determinants of voluntary turnover. International Journal of Manpower, 22, 600-624.

Quintas, P. (2002). Managing knowledge in a new century', In Little, S., Quintas, P. \& Ray, T. (Eds), Managing knowledge: An essential reader. London: Sage Publishers

Qureshi, Hafeez, A., Sharif, U., Butt, B. Z., \& Bilal, M. (2011). Analysis of mergers and acquisition in banking Sector of Pakistan. Interdisciplinary Journal of Contemporary Research in Business, 3(1), 1281-1292.

Rafferty, A. E., \& Restubog, S. L. D. (2010). The impact of change process and context on change reactions and turnover during a merger. Journal of Management, 36(5), 1309-1338. 
Raukko, M. (2009). Organisational commitment during organisational changes: A longitudinal case study on acquired key employees. Baltic Journal of Management, 4(3), 331-352.

Salopek, J. J. (2005). The new brain drain. T+D. Alexandria, 59(6), 23-25.

Schuler., Randall \& Jackson, S. (2001). HR issues and activities in mergers and acquisitions, European Management Journal, 19(3), 239-253.

Schweiger, D. L., \& Ivancevich, J. (1985), Human resource: The forgotten factors in M\&A. Personal Administrator, 2, 47-61.

Schweiger, D. M., \& Weber, Y., (1989). Strategies for managing human resources during mergers and acquisitions: An empirical investigation. Human Resource Planning, 12(2), 69-86.

Seo, M. G., \& Hill, S. N. (2005). Understanding the human side of merger and acquisition: An integrative framework. Journal of Applied Behavioral Science, 41(4), 422-443.

Shah, P. (2000). Network destruction: The structural implications of downsizing. Academy of Management Journal, 43(1), 101-12.

Shaw, J. D., Gupta, N., \& Delery, J. E. (2005). Alternative conceptualizations of the relationship between voluntary turnover and organisational performance. Academy of Management Journal, 48(1), $50-68$.

Shin, M., Holden, T., \& Schmidt, R. (2001). From knowledge theory to management practice: Towards an integrated approach. Information Processing and Management, 37(2), 335-355.

Sonenshein, S. (2010). We're changing - Or are we? Untangling the role of progressive, regressive and stability narratives during strategic change implementation. Academy of Management Journal, 53(3), 477-512.

Starke, F. A.., Dyck, B., \& Mauws, M. K. (2003). Coping with the sudden loss of an indispensable employee: An exploratory case study. The Journal of Applied Behavioral Science, 39(2), 208-29.

Stewart, T. A. (1998). Intellectual capital: The new wealth of Organisations. UK Nicholas Brealey Publishing.

Sverke, M., \& Hellgren, J. (2001). Exit, voice, and loyalty reactions to job insecurity in Sweden: Do unionized and non-unionized employees differ? British Journal of Industrial Relations, 39(2), 167-182.

Tayeb, H. M. (2005). International human resource management: A multinational company perspective. New York, USA: Oxford University Press Inc. 
Taylor-Bianco, A., \& Schernerhorn Jr, J. (2006). Self-regulation, strategic leadership and paradox in organisational change. Journal of Organisational Change Management, 19(4), 457-470.

Taylor, S. (2005). The employee retention handbook. Mumbai: Jaico Publishing House.

Terry, D. J., Carey, C. J., \& Callan, V. J. (2001). Employee adjustment to an organisational merger: An intergroup perspective. Personality and Social Psychology Bulletin, 27(3), 267-280.

Thompson, S., \& Wright, M. (1995). Corporate governance: The role of restructuring transactions. Economic Journal, 105(430), 690-703.

Tomprou, M., Nikolaou, I., \& Vakola, M. (2012), Experiencing organisational change in Greece: The framework of psychological contract. The International Journal of Human Resource Management, 23(2), 385-405.

Turnley, W. H., \& Feldman, D. C. (2000). The impact of psychological contract violations on exit, voice, loyalty and neglect. Human Relations, 52(7), 895-922.

Ulrich, D., Brockbank, W., Johnson, D., Sandhol, K.,. \& Younger, J. (2008). HR competencies. USA: Society for Human Resource Management.

Vazirani, N. (2012). Mergers and acquisitions performance evaluation - A literature review. SIES Journal of Management, 8(2), 37-42.

Wah, L. (1999). Making knowledge stick. Management Review, 88(5), 24-9.

Walsh, J. P., \& Ungson, G. R. (1991). Organisational memory. Academy of Management Review, 16(1), 57-91.

Weiss, D. S. (2013). Leadership driven HR: Canada: John Wiley \& Sons Canada Ltd.

Wong, W. L. P., \& Radcliffe, D. F. (2000). The tacit nature of design knowledge. Technology and Strategic Management, 12(4), 493-512

Wright, M., Hoskisson, R. E., and Busenitz, L. W. (2001). Firm rebirth: Buy-outs as facilitators of strategic growth and entrepreneurship. Academy of Management Executive, 1(15), 111-25.

Zack, M. H. (1999). Managing Codified Knowledge. Sloan Management Review, 40, 45-58. 